\title{
Principal Component Analysis of Tomato Genotypes Based on Some Morphological and Biochemical Quality Indicators
}

\author{
Svetlana Glogovac • Adam Takač • Aleksandra Tepić • Zdravko Šumić • \\ Jelica Gvozdanović-Varga • Janko Červenski • Mirjana Vasić • Vukašin Popović
}

\author{
received: 31 August 2012, accepted: 10 December 2012 \\ (C) 2012 IFVC \\ doi: $10.5937 /$ ratpov49-2452
}

\begin{abstract}
Summary: This study investigates variability of tomato genotypes based on morphological and biochemical fruit traits. Experimental material is a part of tomato genetic collection from Institute of Filed and Vegetable Crops in Novi Sad, Serbia. Genotypes were analyzed for fruit mass, locule number, index of fruit shape, fruit colour, dry matter content, total sugars, total acidity, lycopene and vitamin C. Minimum, maximum and average values and main indicators of variability $(C V$ and $\sigma)$ were calculated. Principal component analysis was performed to determinate variability source structure. Four principal components, which contribute $93.75 \%$ of the total variability, were selected for analysis. The first principal component is defined by vitamin $\mathrm{C}$, locule number and index of fruit shape. The second component is determined by dry matter content, and total acidity, the third by lycopene, fruit mass and fruit colour. Total sugars had the greatest part in the fourth component.

Key words: biochemical traits, fruit quality, morphological traits, PCA, principal component analysis, tomatoes, variability
\end{abstract}

\section{Introduction}

Tomato (Lycopersicum esculentum Mill.) belongs to the nightshade family Solanaceae and is considered one of the most important and world's major traded vegetable. This plant species, ranked $1^{\text {st }}$ in the world for vegetables, accounts for $14 \%$ of world production (FAO 2010). Tomato fruit is widely used in human nutrition, as fresh, ripe fruit and also in the form of different products (Takač et al., 2007). The useful tomato effects in human nutrition are mainly related to antioxidants, lycopene and $\beta$-carotene. Carotenoids have a very important role in human nutrition and disease prevention (Ye et al., 2000). Worldwide consumption of tomatoes requires use

S. Glogovac* • A. Takač • J. Gvozdanović-Varga •

J. Červenski • M. Vasić • V. Popović

Institute of Field and Vegetable Crops, Maksima Gorkog 30,

21000 Novi Sad, Serbia

e-mail: svetlana.glogovac@ifvcns.ns.ac.rs

A. Tepić • Z. Šumić

University of Novi Sad, Faculty of Technology, Bul. Cara Lazara 1,

21000 Novi Sad, Serbia of high-yielding varieties and hybrids. Pursuit of achieving the highest possible yields with higher fruit firmness led to a deterioration of fruit quality. Breeding strategies are not only focused on the yield enhancement and disease resistance any more, but also on the improvement of fruit quality, due to the recent medical research on tomato effects on human health. Taking into account very narrow genetic base of the most widely grown cultivars, significance of divergent initial material in breeding programs is remarkable. There is much more diversity in old cultivars (heirloom tomatoes), wild forms and local populations, and therefore they represent significant source of desirable genes. Authors Takač et al. (2005) emphasize the importance of these local populations because of their good adaptability and fruit quality. Institute of Field and Vegetable Crops in Novi Sad, Serbia contributes to the preservation,

Acknowledgements: This study is a part of the project TR 31030 "Development of vegetable cultivars and hybrids intended for outdoor and indoor production" financed by the Ministry of Education, Science and Technological Development of the Republic of Serbia. 
examination and maintenance of tomato collection.

The objective of this paper was to study genetic diversity of a part of that collection in terms of some fruit quality parameters.

\section{Materials and Methods}

Theexperimental material comprised of ten tomato genotypes which included four local populations (Bitoljski kasni, Bitoljski rani, Đevđelijski, Tetovski) and six old cultivars (Novosadski rani, Novosadski export, Golden jubilei, Saint Pierre, Rutgers, Novosadski jabučar). The field trail was arranged in a randomized complete block design with three replications, two rows in each, at Rimski šančevi site (near Novi Sad, Serbia) during the season of 2008. Space between rows was $1.4 \mathrm{~m}$ and between plants in a row $0.5 \mathrm{~m}$. The observations were recorded on the following fruit traits: fruit mass, dry matter content (total solids), total sugars, total acidity, lycopene, vitamin $\mathrm{C}$, locule number, index of fruit shape and fruit colour.

Total solids were determined by drying the samples at $105^{\circ} \mathrm{C}$ until constant mass was obtained. Titratable acidity was determined volumetrically by titration with $\mathrm{NaOH}$ standard solution. Sugar content was determined by the method of LuffSchoorl. This chemical analysis was performed in accordance with established national regulations (Pravilnik o metodama uzimanja uzoraka i vršenja hemijskih i fizičkih analiza radi kontrole kvaliteta proizvoda od voća i povrća, 1983). Vitamin C content was measured by HPLC analysis at the HPLC system (Agilent 1100, USA) equipped with C-8 column and DAD detector. Lycopene content was determined spectrophotometrically (Vračar, 2001), after separation by column chromatography. Stationary phase was the mixture of $\mathrm{Al}_{2} \mathrm{O}_{3}$ and $\mathrm{MgO}$ (1:1), previously activated at $400^{\circ} \mathrm{C}$. The mobile phase was the mixture of hexane:methanol (9:1).

Principal component analysis was used to determine the source and structure of variation as well as contribution of the observed characteristics in total variability. As a method of multivariate analysis, it performs the transformation of the initial variables into a limited number of uncorrelated new variables. Data were processed in the statistical software Statistica 9 (StatSoft Inc. Corporation, Tulsa, USA).

\section{Results and Discussion}

Minimum, maximum and average values were calculated for the analyzed genotypes, as well as coefficient of variation and standard deviation as main indicators of variability (Table 1).

Table 1. Investigated tomato genotypes and mean values of morphological and biochemical fruit traits Tabela 1. Analizirani genotipovi paradajza i prosečne vrednosti morfoloških i biohemijskih svojstava ploda

\begin{tabular}{lccccccccc}
\hline Genotype & FM & DM & TS & TA & LYC & VIT C & LN & FI & FC $^{*}$ \\
\hline Bitoljski kasni & 98.2 & 6.3 & $\mathbf{9 4 . 8}$ & 6.0 & $\mathbf{1 5 5 0 . 9}$ & 832.2 & 3.9 & 0.8 & 4 \\
Bitoljski rani & 49.3 & 5.6 & 53.1 & 6.6 & 796.5 & 937.8 & 2.8 & 0.8 & 4 \\
Đevđelijski & 65.1 & 5.5 & 82.5 & 6.9 & 1437.1 & 721.5 & 2.0 & 1.0 & 4 \\
Tetovski & 54.0 & 6.1 & 54.0 & 4.6 & 910.9 & 846.0 & 2.8 & 1.0 & 4 \\
Novosadski rani & 118.1 & 5.4 & 70.2 & $\mathbf{8 . 6}$ & 912.1 & $\mathbf{1 0 2 7 . 1}$ & $\mathbf{1 0 . 2}$ & $\mathbf{0 . 5}$ & 4 \\
Novosadski export & 91.4 & 5.7 & 70.0 & 6.8 & 983.5 & 650.4 & 2.2 & 0.9 & 4 \\
Golden jubilei & 170.1 & 6.1 & 72.8 & 8.2 & 320.0 & 793.9 & 4.7 & 0.9 & $\mathbf{2}$ \\
Saint Pierre & 150.0 & 6.3 & 73.6 & 5.7 & 916.0 & 863.7 & 4.8 & 0.9 & 4 \\
Rutgers & $\mathbf{2 0 0 . 0}$ & $\mathbf{6 . 8}$ & 60.6 & 5.0 & 1135.9 & 954.1 & 6.5 & 0.8 & 4 \\
Novosadski jabučar & 125.2 & 6.3 & 51.0 & 6.2 & 1187.0 & 949.1 & 3.9 & 0.9 & 4 \\
\hline Mean & 112.1 & 6.0 & 68.2 & 6.5 & 1015.0 & 857.6 & 4.4 & 0.9 & - \\
Min & 49.3 & 5.4 & 51.0 & 4.6 & 320.0 & 650.4 & 2.0 & 0.5 & - \\
Max & 200.0 & 6.8 & 94.8 & 8.6 & 1550.9 & 1027.1 & 10.2 & 1.0 & - \\
CV\% & 44.97 & 7.6 & 20.44 & 19.49 & 34.01 & 13.42 & 56.19 & 16.87 & - \\
$\sigma$ & 50.42 & 0.46 & 13.95 & 1.26 & 345.22 & 115.05 & 2.46 & 0.14 & - \\
\hline
\end{tabular}

"Fruit color according to the UPOV descriptors: 1- yellow; 2-orange; 4-red

FM-fruit mass (g); DM-dry matter (\%); TS-total sugars(g/100 g dm); TA-total acidity(g/100 g dm); LYC-lycopene (mg/100 gdm); VIT $C$-vitamin $C(m g / 100 \mathrm{gdm}) ; \mathrm{LN}$ - locule number; FI- fruit index; FC-fruit color 
Number of components which would be retained in further analysis was defined according to relations between the eigenvalues (Figure 1). Contribution of the first four components in total variance was shown, expressed in percentage, as well as the characteristics which were crucial for components defining (Table 2).
The first component accounts for approximately $32.93 \%$ of the total variance. The most important traits in the first principal component were: vitamin $\mathrm{C}$, locule number and index of fruit shape.

It is known that vitamin $\boldsymbol{C}$ (ascorbic acid) has an important role in biochemical processes, neurotransmission and immunity (Martinez,

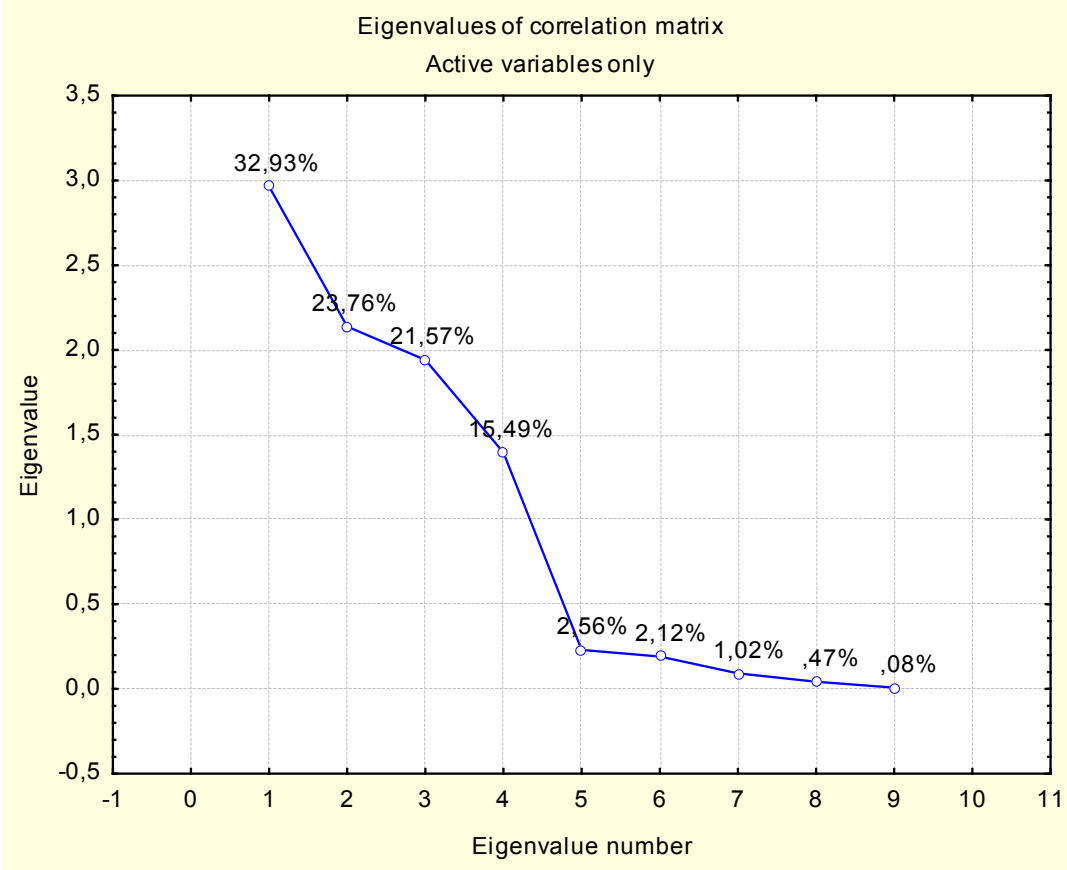

Figure 1. Percentage of variability explained by main principal components Grafik 1. Procenat varijabilnosti objašnjen glavnim komponentama

Table 2. Rotated components of nine tomato traits

Tabela 2. Rotirane komponete za devet ispitivanih svojstva paradajza

\begin{tabular}{lcccc}
\hline \multirow{2}{*}{ Variable } & \multicolumn{4}{c}{ Main components } \\
\cline { 2 - 5 } & PCA 1 & PCA 2 & PCA 3 & PCA 4 \\
\hline Dry matter & 0.032192 & -0.743874 & 0.589661 & -0.274169 \\
Total sugars & 0.100607 & 0.354708 & -0.142242 & -0.888827 \\
Lycopene & 0.447678 & -0.384416 & -0.572140 & -0.501460 \\
Vitamin C & -0.692987 & -0.532220 & -0.240318 & 0.275819 \\
Total acidity & -0.556331 & 0.776033 & -0.132577 & -0.092937 \\
Fruit mass & -0.560052 & -0.334688 & 0.589762 & -0.395496 \\
Locule number & -0.925281 & -0.185896 & -0.179431 & -0.157909 \\
Fruit index & 0.835553 & 0.031070 & 0.484349 & 0.094214 \\
Fruit colour & 0.307506 & -0.527287 & -0.745539 & 0.051535 \\
\hline Eigenvalue & 2.963821 & 2.137996 & 1.941044 & 1.394242 \\
\% Total variance & 32.93135 & 23.75551 & 21.56715 & 15.49158 \\
Cumulative \% & 32.9313 & 56.6869 & 78.2540 & $\mathbf{9 3 . 7 4 5 6}$ \\
\hline
\end{tabular}


1998). High content of vitamin C in tomato fruit determinates its high biological value. However, ascorbic acid content is highly unstable and varies greatly depending on environmental conditions. In the assessed material, vitamin $\mathrm{C}$ content ranged from 650.4 to $1027.1 \mathrm{mg} / 100 \mathrm{~g} \mathrm{dm}$, with CV $13.42 \%$. The richest genotype in vitamin C was Novosadski rani, while the least content was measured in the variety Novosadski export.

Locule number has an influence on the fruit shape and size. In the analyzed genotypes locule number ranged from 2.0 to 10.2 with $C V$ $56.19 \%$. Local population Đevđelijski, with the smallest fruit (after populations Bitoljski rani and Tetovski), had the lowest locule number, while cultivar Novosadski rani, with the most flattened fruit had the highest locule number in the examined material.

Fruit shape is usually calculated as fruit height and width ratio, known as "fruit shape index" (Gonzalo \& Van der Knaap, 2008). Round fruits of uniform size are favourable for manual harvesting, while elongated fruits facilitate mechanical harvesting. Fruit index ranged from 0.5 to 1.0 with $C V 16.87 \%$. Novosadski rani had the lowest index of fruit shape and the most flattened, ribbed fruit. Although consumers' demands are different, most of them require round tomatoes with uniform size.

The second component accounts for approximately $23.76 \%$ of the total variance. This component is defined by dry matter content and total acidity.

Dry matter content is a very important indicator of fruit quality, both for canning industry and fresh consumption. Dry matter of tomato fruit is comprised of water-soluble dry matter (about 88\%) originating mainly from sugars, acids, proteins and water-soluble pectic substances (pectinic acid). Cellulose, hemicellulose, pectic acid and protopectin are water-insoluble components (Tepić et al., 2006). Tomatoes with high dry matter content are highly desirable in processing as they significantly increase the quality of the processed product (De Pascale et al., 2001). Determined dry matter values ranged from 5.4 to $6.8 \%$ with $C V 7.6 \%$. The highest value was measured in old cultivar Rutgers, while cultivar Novosadski rani had the least dry matter content. Majority of analyzed genotypes had dry matter content above $6.0 \%$.
Acids content is very important for fruit flavour and for quality of processed tomato. The most common acids in tomato fruit are: citric, malic and oxalic. The amount of organic acids in tomato fruits depends on the variety, degree of maturity and growing conditions. The lowest acids content $(4.6 \mathrm{~g} / 100 \mathrm{~g} \mathrm{dm})$ was measured in local population Tetovski, while cultivar Novosadski rani was characterized with the highest acidity value $(8.6 \mathrm{~g} / 100 \mathrm{~g} \mathrm{dm})$. This quality parameter had $C V 19.49 \%$ in the analyzed material.

The third principal component contributes $21.57 \%$ of the total variance. The most important traits in this component were: lycopene, fruit mass and fruit colour.

Tomato is one of the main sources of lycopene. Carotenoid lycopene is a natural antioxidant, very important in prevention of many diseases. The fact that human organism is not able to synthesize lycopene increases the importance of tomato in nutrition, and therefore in breeding programs. Varieties rich in lycopene are very important for industrial processing and for fresh consumption as well, since consumers are demanding food with high nutraceutical values. Analyzed genotypes were very divergent in lycopene content since it ranged from 320.0 to $1,550.9 \mathrm{mg} / 100 \mathrm{~g} \mathrm{dm}$ with $C V 34.01 \%$. The highest amount of lycopene was established in local population Bitoljski kasni, while the least amount of lycopene was measured in cultivar Golden jubilei, since it has orange fruit colour.

Fruit mass depends on many factors: varieties, environmental conditions, type of growing, etc. Depending on the mass, fruits are classified into groups: large $(120-250 \mathrm{~g})$, medium $(80-120 \mathrm{~g})$, small $(60-80 \mathrm{~g})$ and also cocktail $(30-50 \mathrm{~g})$ and cherry types (10-30 g) (Đurovka et al., 2006). Fruit mass varied from 49.3 to $200.0 \mathrm{~g}$ with $C V$ $44.97 \%$. Bearing in mind that this trait defines cultivar purpose, divergence of genetic material in fruit mass is very significant for breeding programs. Old cultivar Rutgers had the highest fruit mass, and also the highest dry matter content, among all analyzed genotypes. Local population Bitoljski rani had the lowest fruit mass.

Colour is an important quality indicator. Depending on structures and concentrations of carotenoids (lycopene, $\beta$-carotene, $\zeta$-carotene, etc.) tomato colour may be: red, orange, yellow, purple, or even white. All analyzed genotypes had red fruits apart from one cultivar, Golden jubilei. 
There is a correlation between fruit colour and total antioxidant concentration, with lycopene increasing from the rose to red colour stages. Brandt et al. (2006) emphasized the increase of red colour intensity with increase of lycopene content.

The fourth main component explained 15.49\% of total variability with total sugars as the most important trait. Total sugar content and acidity are of the highest importance for fruit taste (Rodica et al., 2008). Total sugars ranged between 51.0 and $94.8 \mathrm{~g} / 100 \mathrm{~g} \mathrm{dm}$ with $C V 20.44 \%$. The highest value of total sugars was measured in cultivar Bitoljski kasni, while cultivar Novosadski jabučar had the least sugar content.

\section{Conclusions}

The variability of the investigated morphological and biochemical traits was determined for all genotypes included in the analysis. The highest variability was established in locule number $(\mathrm{CV}$ 56.19\%), fruit mass (CV 44.97\%) and lycopene content (CV34.01\%).

Genotypes with high dry matter and lycopene content and different fruit mass depending on harvesting method should be used for creation of varieties intended for industrial purposes. Genotypes with balanced sugars/acids ratio, high dry matter, lycopene and vitamin $\mathrm{C}$ content are desirable for creation of cultivars for fresh consumption.

High content of dry matter, lycopene, total sugars and vitamin $\mathrm{C}$ was determined in most of the genotypes. Since consumers demand highquality tomatoes with good flavour, as is the case in traditional varieties, and food that prevents different diseases, analyzed genotypes should be used in organic production and in breeding process to increase fruit quality.

\section{References}

Brandt, S., Pék, Z., Barna, É., Lugasi, A., \& Helyes, L. (2006). Lycopene content and colour of ripening tomatoes as affected by environmental conditions. Journal of the Science of Food and Agriculture, 86(4), 568-572. doi: $10.1002 /$ jsfa. 2390

De Pascale, S., Maggio, A., Fogliano, V., Ambrosino, P., \& Retieni, A. (2001). Irrigation with saline water improves carotenoids content and antioxidant activity of tomato. The Journal of Horticultural Science \& amp; Biotechnology, 76, 447-453.

Đurovka, M., Lazić, B., Bajkin, A., Potkonjak, A., Marković, V., Ilin, Ž., \& Todorović, V. (2006). Proizvodnja povrća i cveća u zaśtićenom prostoru. Novi Sad: Poljoprivredni fakultet.

Gonzalo, M. J., \& Knaap, E. (2008). A comparative analysis into the genetic bases of morphology in tomato varieties exhibiting elongated fruit shape. Theoretical and Applied Genetics, 116(5), 647-656. doi: 10.1007/s00122-0070698-7

Martínez, J. A. (1998). Fundamentos teórico-prácticos de Nutrición y dietética. España: McGraw-Hill, Interamericana.

Pravilnik o metodama uzimanja uzoraka i vršenja hemijskih i fizičkih analiza radi kontrole kvaliteta proizvoda od voća i povrća. Službeni list SFRJ, (1983). 29.

Rodica, S., Apahidean, S.A., Apahidean, M., Manitiu, D., \& Paulette, L. (2008). Yield, Physical and Chemical Characteristics of Greenhouse Tomato Grown on Soil and Organic Substratum. In: 43rd Croatian and 3rd International Symposium on Agriculture. Opatija, Croatia. 439-443.

Takač, A., Gvozdenović, Đ., Gvozdanović-Varga, J., Vasić, M., \& Bugarski, D. (2005). Characteristics of old tomato cultivars. Natura Montenegrina, 4, 83-91.

Takač, A., Gvozdenović, Đ., Bugarski, D., \& Červenski, J. (2007). Savremena proizvodnja paradajza. Zbornik radova Instituta za ratarstvo i povrtarstvo. 43 (1), 269-281.

Tepić, A. N., Vujičić, B. L., Takač, A. J., Krstić, B. Đ., \& Čalić, L. J. (2006). Chemical heterogenity of tomato inbred lines. Acta periodica technologica. 37, 45-50.

Vračar, L. O. (2001). Priručnik za kontrolu kvaliteta svežeg i preradenog voća, povrća i pečurki i osvežavajućih bezalkoholnih pića. Novi Sad: Tehnološki fakultet.

www.fao.org

Ye, X., Al-Babili, S., Kloti, A., Zhang. J., Lucca, P., Beyer, P., \& Potrykus, I. (2000). Engineering the provitamin A (beta-carotene) biosynthetic pathway into (carotenoidfree) rice endosperm. Science. 287(5451), 303-5. doi: $10.1126 /$ science. 287.5451 .303 


\title{
Metoda glavnih komponenata u analizi morfoloških i biohemijskih parametara kvaliteta paradajza
}

\author{
Svetlana Glogovac • Adam Takač • Aleksandra Tepić • Zdravko Šumić • \\ Jelica Gvozdanović-Varga • Janko Červenski • Mirjana Vasić • Vukašin Popović
}

Izvod: Cilj istraživanja je bio da se ispita genetička varijabilnost genotipova paradajza na osnovu morfoloških i biohemijskih osobina ploda. Eksperimentalni materijal predstavlja deo genetske kolekcije paradajza Instituta za ratarstvo i povrtarstvo u Novom Sadu. Ispitivane su sledeće osobine ploda: masa, broj komora, indeks oblika, boja, sadržaj suve materije, ukupni šećeri, ukupna kiselost, sadržaj likopena i vitamina C. Izračunate su minimalne, maksimalne i prosečne vrednosti kao i osnovni pokazatelji varijabilnosti $(C V$ i $\sigma)$. Struktura izvora varijabilnosti utvrđena je primenom metode glavnih komponenata. Četiri glavne komponente, kojima je objašnjeno 93,75\% ukupne varijabilnosti, odabrano je za dalju analizu. Najveći udeo u prvoj glavnoj komponenti imali su vitamin C, broj komora i indeks oblika ploda. Druga komponenta je objašnjena sadržajem suve materije i ukupnih kiselina, a treća sadržajem likopena, bojom i masom ploda. Ukupni šećeri imali su najveći udeo u četvrtoj glavnoj komponenti. Ključne reči: biohemijske osobine, kvalitet ploda, metoda glavnih komponenata, morfološke osobine, paradajz, PCA, varijabilnost 